\title{
Candida soluble cell wall $\beta$-glucan facilitates ovalbumin-induced allergic airway inflammation in mice: Possible role of antigen-presenting cells
}

\author{
Ken-ichiro Inoue*1, Hirohisa Takano ${ }^{1}$, Eiko Koike ${ }^{1}$, Rie Yanagisawa1, \\ Toshio Oda ${ }^{2}$, Hiroshi Tamura ${ }^{2}$, Yoshiyuki Adachi ${ }^{3}$, Ken-ichi Ishibashi ${ }^{3}$ and \\ Naohito Ohno ${ }^{3}$
}

\begin{abstract}
Address: ${ }^{1}$ Environmental Health Sciences Division, National Institute for Environmental Studies, Tsukuba, Ibaraki 305-8506, Japan, ${ }^{2}$ Seikagaku Biobusiness Corporation, Tokyo, Japan and ${ }^{3}$ Laboratory for Immunopharmacology of Microbial Products, School of Pharmacy, Tokyo University of Pharmacy and Life Science, Japan

Email: Ken-ichiro Inoue* - inoue.kenichirou@nies.go.jp; Hirohisa Takano - htakano@nies.go.jp; Eiko Koike - ekoike@nies.go.jp; Rie Yanagisawa - yanagi@nies.go.jp; Toshio Oda - toshio.oda@seikagakubb.co.jp; Hiroshi Tamura - hiroshi.tamura@seikagakubb.co.jp; Yoshiyuki Adachi - adachi@ps.toyaku.ac.jp; Ken-ichi Ishibashi - ishiken@ps.toyaku.ac.jp; Naohito Ohno - ohnonao@ps.toyaku.ac.jp

* Corresponding author
\end{abstract}

Published: 21 July 2009

Respiratory Research 2009, 10:68 doi:10.1 186/1465-9921-10-68

This article is available from: http://respiratory-research.com/content//0///68

(c) 2009 Inoue et al; licensee BioMed Central Ltd.

This is an Open Access article distributed under the terms of the Creative Commons Attribution License (http://creativecommons.org/licenses/by/2.0), which permits unrestricted use, distribution, and reproduction in any medium, provided the original work is properly cited.
Received: 8 April 2009

Accepted: 21 July 2009

\begin{abstract}
Background: Although fungi have been implicated as initiating/deteriorating factors for allergic asthma, their contributing components have not been fully elucidated. We previously isolated soluble $\beta$-glucan from Candida albicans (CSBG) (Ohno et al., 2007). In the present study, the effects of CSBG exposure on airway immunopathology in the presence or absence of other immunogenic allergen was investigated in vivo, and their cellular mechanisms were analyzed both in vivo and in vitro.
\end{abstract}

Methods: In vivo, ICR mice were divided into 4 experimental groups: vehicle, CSBG (25 $\mu$ g/animal), ovalbumin (OVA: $2 \mu \mathrm{g} / \mathrm{animal}$ ), and CSBG + OVA were repeatedly administered intratracheally. The bronchoalveolar lavage cellular profile, lung histology, levels of cytokines and chemokines in the lung homogenates, the expression pattern of antigen-presenting cell (APC)-related molecules in the lung digests, and serum immunoglobulin values were studied. In vitro, the impacts of CSBG $(0-12.5 \mu \mathrm{g} / \mathrm{ml})$ on the phenotype and function of immune cells such as splenocytes and bone marrow-derived dendritic cells (BMDCs) were evaluated in terms of cell proliferation, the surface expression of APC-related molecules, and OVA-mediated T-cell proliferating activity.

Results: In vivo, repeated pulmonary exposure to CSBG induced neutrophilic airway inflammation in the absence of OVA, and markedly exacerbated OVA-related eosinophilic airway inflammation with mucus metaplasia in mice, which was concomitant with the amplified lung expression of Th2 cytokines and IL-I7A and chemokines related to allergic response. Exposure to CSBG plus OVA increased the number of cells bearing MHC class II with or without CD80 in the lung compared to that of others. In vitro, CSBG significantly augmented splenocyte proliferation in the presence or absence of OVA. Further, CSBG increased the expression of APC-related molecules such as CD80, CD86, and DEC205 on BMDCs and amplified OVA-mediated T-cell proliferation through BMDCs.

Conclusion: CSBG potentiates allergic airway inflammation with maladaptive Th immunity, and this potentiation was associated with the enhanced activation of APCs including DC. 


\section{Background}

Bronchial asthma has been recognized as a chronic type of allergic airway inflammation with hyperresponsiveness to foreign allergens. Almost all allerologists know that allergy including asthma involves a significant genetic component; however, to explain the rapid rise in the prevalence of asthma and allergic diseases over the past 40 years, we must consider environmental factors and triggers [1]. Thus, understanding the nature of environmental triggers is fundamental in attempts to prevent/reduce allergic diseases, in particular, in the next generation. As previously noted, among environmental triggers/factors, exposure to common aeroallergens, especially perennial inhalable allergens such as house dust mite, companion animal allergens, cockroach allergen, and pollutants, is associated with a significantly increased risk for asthma $[2,3]$. Fungal spores are also important, since their growth is a common problem in moisture- and water-damaged buildings [3-5]. Given the evidence of the importance of exposure to fungi including molds as an environmental risk factor for asthma, some epidemiological data have been reported on the link between airborne fungi and asthmatic subjects $[6,7]$, e. g. exposure to fungi in indoor air is thought to induce allergic asthma in susceptible subjects [8]. More importantly, fungi may increase allergic reactions to other allergens as adjuvants [8]. However, there is still a shortage of experimental evidence regarding the correlation between fungi and allergic diseases. Furthermore, it remains unknown which components of the fungal organisms are responsible for the induction/adjuvant effects on allergic asthma.

$\beta$-glucan of fungi reportedly possesses various biological activities $[9,10]$, being implicated in the development of mycosis. However, the activities of the component have not been appropriately elucidated, because it cannot be solubilized easily in water and alkali solutions, resulting in a difficulty to examine it experimentally [11]. We have succeeded in the extraction of a soluble $\beta$-glucan from $C$. albicans (CSBG), recognized to be a major opportunistic pathogen in humans, and analyzed its biological effects [12]. We previously reported its immunopharmacological activities such as the production of proinflammatory cytokines in vitro [13] and antitumor activity in vivo [14]. Also, we demonstrated that a single pulmonary exposure to CSBG induces lung inflammation characterized by the infiltration of inflammatory leukocytes including eosinophils with an enhanced lung expression of proinflammatory cytokines and chemokines, with a possible link to the activation of signal transducer and activator of transcription (STAT)6 [15], implicating that CSBG can induce/facilitate allergic airway inflammation, in which STAT6 pathway plays an important role. Furthermore, some previous studies have implied that gastrointestinal tract colonization by Candida enhances allergic airway responses in vivo [16,17] and in humans [18].
The present study explored whether repetitive pulmonary exposure to CSBG induces allergic type airway inflammation and/or potentiates other allergen (ovalbumin: OVA)induced allergic airway inflammation in mice. Further, we examined the impact of CSBG on immune cells such as splenocytes and bone marrow-derived dendritic cells (BMDCs) in vitro to identify cellular mechanisms underlying CSBG's facilitation on allergic inflammation.

\section{Methods \\ Reagents}

CSBG was purified using the NaClO-DMSO method from the yeast form of C. albicans NBRC1385 cultured on Climitting medium, as previously described [13]. Briefly, $C$. albicans was oxidized with $\mathrm{NaClO}$ solution, and the resulting insoluble part was collected and extensively washed and dialyzed with distilled water. Finally, the insoluble part ( $\mathrm{NaClO}$-oxidized candida: OX-CA) was dried by acetone and ether. OX-CA was essentially composed of $\beta$-glucan and free from nitrogen based on elemental analysis. CSBG was extracted from OX-CA by dimethyl sulfoxide (DMSO: Sigma Chemical, St. Louis, MO) and precipitated using acetone and ether. Thus, CSBG is a purified preparation of solubilized cell wall $\beta$-glucan of $C$. albicans. The structure of CSBG was determined by elemental analysis, $\beta$-1,3-glucanase digestion, MALDI-TOF-MASS analysis, and NMR spectroscopy as $\beta$-1,3-glucan carrying $\beta-1,6-\beta$ segment [13]. The activity of OX-CA (parent material of CSBG) was completely dependent on dectin- 1 , a $\beta$-glucan receptor, by using alveolar macrophage from dectin-1 knockout mice, suggesting that CSBG is a ligand of dectin1 [19]. CSBG was dissolved in DMSO. The endotoxin activity which was determined using the Limulus Amebocyte Lysate assay (Seikagaku-kogyo, Tokyo, Japan), was lower than the detection limit $(0.001 \mathrm{EU} / \mathrm{ml})$ in the vehicle and CSBG.

\section{Animals}

Male ICR mice 6 wk of age (Japan Clea Co., Tokyo, Japan) were used for the in vivo studies; mice 11-13 wk of age were used for in vitro studies. Mice were housed in an animal facility maintained at 24 to $26^{\circ} \mathrm{C}$ with 55 to $75 \%$ humidity and a 12-h light/dark cycle, and fed a commercial diet (Japan Clea Co.) and given water ad libitum. The studies adhered to the National Institutes of Health guidelines for the experimental use of animals. All animal studies were approved by the Institutional Review Board of the National Institute for Environmental Studies.

\section{In vivo studies \\ Study protocol}

Mice were divided into four experimental groups. The vehicle group received vehicle (phosphate-buffered saline: PBS at pH 7.4 [Invitrogen Co., Carlsbad, CA, USA] containing 2\% DMSO) every $2 \mathrm{wk}$ for $4 \mathrm{wk}$ (total: 3 times). The OVA group received $2 \mu \mathrm{g}$ of OVA (Grade IV: 
Sigma Chemical: endotoxin activity was lower than the detection limit) dissolved in the same vehicle every $2 \mathrm{wk}$ for $4 \mathrm{wk}$ (total: 3 times) to elicit allergic airway inflammation according to the previous study by our laboratory [20]. The CSBG group received (12.5 or) $25 \mu \mathrm{g}$ of CSBG suspended in the same vehicle every $2 \mathrm{wk}$ for $4 \mathrm{wk}$ (total: 3 times). This protocol was confirmed to significantly facilitate this type of allergic asthma when intratracheally administered 3 times, since the effect of a 6-times CSBG exposure on the pathology was not different from a 3times exposure. The CSBG + OVA group received the combined treatment using the same protocol as the OVA and CSBG groups, respectively. In each group, vehicle, CSBG, OVA, or CSBG + OVA was dissolved in 0.1-ml aliquots, and inoculated by the intratracheal route through a polyethylene tube under anesthesia with $4 \%$ halothane (Hoechst, Japan, Tokyo, Japan). Twenty-four h after the last intratracheal administration, mice were sacrificed and sera and the lungs were collected for bronchoalveolar lavage (BAL) cellularity, lung histology, lung cytokine profile, and OVA-specific antibody assay. In other experiments, $4 \mathrm{~h}$ after the last intratracheal administration, mice were sacrificed and the lungs were collected for FACS analysis.

\section{$B A L$ and histological evaluation}

BAL and cell counts were conducted as previously described [20-22] ( $\mathrm{n}=8$ in each group). After the BAL procedure, the lungs were removed, snap-frozen in liquid nitrogen, and stored at $-80^{\circ} \mathrm{C}$ for ELISA. Histological evaluation was conducted using hematoxylin and eosin (H\&E) staining (International Reagents Co., Kobe, Japan) or periodic acid-Schiff (PAS) ( $\mathrm{n}=5$ in each group), as previously described $[21,22]$.

\section{Morphometric analysis of numbers of polymorphonuclear leukocytes (PMNs), mononuclear cells (MONs), and mucus cells}

On another occasion, sections were stained with DiffQuik to quantify the numbers of infiltrated PMNs and MONs. The length of the basement membrane of airways was measured by videomicrometer (Olympus Co., Tokyo, Japan) in each sample slide. The numbers of PMNs and MONs around the airways were counted with a micrometer under oil immersion. The results are expressed as the number of inflammatory cells per millimeter of basement membrane, as described previously [21] $(n=5$ in each group). To quantify mucus cells, sections were stained with PAS. The number of mucus cells in the bronchial epithelium was counted using a micrometer. The results are expressed as the number of mucus cells per millimeter of basement membrane, as described previously [21] ( $\mathrm{n}=5$ in each group).

\section{Quantification of cytokines in lung tissue homogenates}

Frozen lungs were subsequently homogenized, as described previously $[21,22]$. ELISAs for interleukin (IL)-
4 (Amersham, Buckinghamshire, UK), IL-5 (Endogen, Cambridge, MA), IL-13 (R\&D systems, Minneapolis, $\mathrm{MN}$ ), interferon (IFN)- $\gamma$ (Endogen), IL-17A (BioLegend, Inc., San Diego, CA), granulocyte/macrophage-colonystimulating factor (GM-CSF), eotaxin, macrophage inflammatory protein (MIP)-1 $\alpha$, and keratinocyte-derived chemoattractant $(\mathrm{KC})(\mathrm{R} \& \mathrm{D}$ systems) in the lung tissue homogenates were conducted according to the manufacturer's instructions ( $\mathrm{n}=8$ in each group).

\section{Total IgE and OVA-specific Ig determination}

Total IgE, OVA-specific IgG Ig $_{1} \operatorname{IgG}_{2 a^{\prime}}$ or IgE antibodies was measured by ELISA using sera obtained from blood, as previously described $[20,21]$. In brief, for total IgE, microplate wells were coated with a rat anti-mouse IgE monoclonal antibody (Yamasa Syoyu Co., Chiba, Japan) and diluted samples were introduced. After incubation, biotinylated rat anti-mouse IgE (BD Biosciences Pharmingen, San Diego, CA) was added to each well. Thereafter, the wells were incubated with 4 -methylumbelliferyl- $\beta$-galactoside (Sigma Chemical) as the enzyme substrate. The fluorescene intensity was read by a microplate fluorescene reader (Fluoroskan Flow Laboratories, Costa Mesa, CA)(n $=13$ in each group). For OVA-specific $\operatorname{IgG}_{1}$ and $\operatorname{IgG}_{2 a^{\prime}}$ microplate wells (Dynatech, Chantilly, VA) were coated with OVA. Diluted samples were added to the microplate and the bound $\operatorname{IgG}_{1}$ was detected with biotinylated rabbit anti-mouse $\operatorname{IgG}_{1}$ or $\operatorname{IgG}_{2 \mathrm{a}}$ (Zymed Laboratories, San Francisco, CA). Color development was achieved using horseradish-peroxidase-conjugated streptavidin (Sigma Chemical) followed by the addition of o-phenylenediamine and $\mathrm{H}_{2} \mathrm{O}_{2}$. Optimal density readings of samples at $492 \mathrm{~nm}$ were obtained, and results were expressed in titers calculated based on the titers of the standard serum ( $\mathrm{n}=$ 13 in each group). OVA-specific IgE was measured using an ELISA kit (Dainippon Sumitomo Pharmaceutical Co., Osaka, Japan) according to the manufacturer's instructions. Subtractive readins at $450 \mathrm{~nm}$ was converted to $\mathrm{ng} /$ $\mathrm{ml}$ using values obtained from standard curves generated with varying concentrations of anti-OVA antibodies ( $\mathrm{n}=$ 13 in each group).

\section{Preparation of lung cells and FACS analysis}

Mice were anesthetized with sodium pentobarbital (Dainippon Sumitomo Pharmaceutical Co.) given intraperitoneally $(50 \mathrm{mg} / \mathrm{kg})$, and exsanguinated from the cut abdominal aorta and vein. The lung cells were prepared as previously described [20]. Briefly, the lung vessel was perfused with $2 \mathrm{ml}$ of chilled PBS containing $0.2 \%$ bovine serum albumin (BSA; Sigma Chemical) and $10 \mathrm{U} / \mathrm{ml}$ heparin (Wako Pure Chemical Industries, Ltd., Osaka, Japan) introduced into the right ventricle. The lung tissue was sliced and digested for $90 \mathrm{~min}$ at $37^{\circ} \mathrm{C}$ in $2 \mathrm{ml}$ of PBS containing $0.2 \%$ BSA, $0.25 \mathrm{mg} / \mathrm{ml}$ collagenase A (Boehringer Mannheim, Mannheim, Germany), and $50 \mathrm{U} / \mathrm{ml}$ DNAase I (Sigma Chemical). After teasing the digested tis- 
sue and filtration through cotton wool, single cell suspensions were collected. The numbers of viable cells were determined by the trypan blue exclusion method.

For FACS analysis, the following monoclonal antibodies were used: MHC class II molecules: I-A/I-E (2G9, FITCconjugated, BD Biosciences Pharmingen); co-stimulatory molecules: CD80 (16-10A1, PE-conjugated, BD Biosciences Pharmingen), CD86 (GL1, PE-conjugated, BD Biosciences Pharmingen), DC markers: CD11c (HL3, PEconjugated, BD Biosciences Pharmingen), DEC-205 (NLDC-145, PE-conjugated, Cedarlane Labs, Ontario, Canada), a macrophage marker: F4/80 (CI:A3-1, PE-conjugated, Serotec, Oxford, UK); a B-cell differentiation antigen: CD19 (6D5, PE-conjugated, Southern Biotechnology, Birmingham, AL). Immunostaining was conducted as previously described $[20,23,24]$, and flow cytometry was performed using a FACSCalibur (Becton, Dickinson and Company, NJ). Fluorescence data are expressed as the percentage of positive cells. Finally, the number of positive cells was calculated and expressed for each group ( $\mathrm{n}=8$ in each group).

\section{In vitro studies}

Preparation of bone marrow cells and splenocytes

Mice were anesthetized with sodium pentobarbital and exsanguinated from the cut abdominal aorta and vein. After removing the surrounding muscle tissue by rubbing with kleenex ${ }^{\otimes}$ tissues, the bones were left in $70 \%$ ethanol for 3 min and washed with Dulbecco's calcium and PBS. Both ends of the bones were cut and then the marrow was flushed with PBS using a syringe with a 25G needle. The marrow suspension was passed through nylon mesh to remove small pieces of bone and debris and red blood cells were lysed with ammonium chloride. The spleen was pushed through a sterile stainless wire mesh (200 mesh) and red blood cells were also lysed with ammonium chloride. The cells were centrifuged at $400 \times \mathrm{g}$ for $5 \mathrm{~min}$ at $20^{\circ} \mathrm{C}$. After washing twice with PBS, the cells were resuspended in the culture medium R10, which was GIBCO RPMI 1640 medium (Invitrogen Co.) supplemented with $10 \%$ heat-inactivated fetal bovine serum (FBS; MP Biomedicals Inc., Eschwege, Germany), $100 \mathrm{U} / \mathrm{ml}$ penicillin, $100 \mu \mathrm{g} / \mathrm{ml}$ streptomycin (Sigma Chemical), and $50 \mu \mathrm{M} 2-$ mercaptoethanol (Invitrogen Co.). The numbers of viable cells were determined by the trypan blue (Invitrogen Co.) exclusion method.

\section{Differentiation of BMDCs}

BMDCs were differentiated using a modified protocol of Lutz et al [25]. In brief, bone marrow cells $\left(4 \times 10^{5} / \mathrm{ml}\right)$ were cultured in R10 medium containing $20 \mathrm{ng} / \mathrm{ml}$ recombinant mouse GM-CSF (Sigma Chemical) at $37^{\circ} \mathrm{C}$ in a $5 \% \mathrm{CO}_{2} / 95 \%$ air atmosphere. On day 3, another same volume of medium was added to the culture. At day 6 of culture, half of the culture medium was poured into fresh R10 medium containing $20 \mathrm{ng} / \mathrm{ml}$ GM-CSF. At day 8 of culture, non-adherent and loosely adherent cells were collected by gentle pipetting, and centrifuged at $400 \times \mathrm{g}$ for $5 \mathrm{~min}$ at $20^{\circ} \mathrm{C}$. These cells (immature BMDC) were resuspended in the medium. The numbers of viable cells were determined by the trypan blue exclusion method.

\section{Exposure to CSBG in vitro}

CSBG was dissolved in PBS. BMDCs were differentiated by culture with GM-CSF as described above. Differentiated BMDCs $\left(1 \times 10^{6} / \mathrm{ml}\right)$ on day 8 of culture with GMCSF $(20 \mathrm{ng} / \mathrm{ml})$ were exposed to CSBG $(1.25-12.5 \mu \mathrm{g} / \mathrm{ml})$ or $0.1 \%$ DMSO (control) in the presence of GM-CSF (10 $\mathrm{ng} / \mathrm{ml}$ ) for $24 \mathrm{~h}$. Thereafter, the phenotypes and function of BMDCs were evaluated in terms of the expression pattern of surface markers and antigen-presenting activity. On the other hand, splenocytes $\left(1 \times 10^{6} / \mathrm{ml}\right)$ were exposed to CSBG $(1.56-12.5 \mu \mathrm{g} / \mathrm{ml})$ or $0.1 \%$ DMSO (control) in the presence or absence of $100 \mu \mathrm{g} / \mathrm{ml}$ OVA for $72 \mathrm{~h}$, and then the cell.

\section{FACS analysis}

For FACS analysis, the following monoclonal antibodies were used: I-A/I-E, CD80, CD86, CD11C, and DEC-205. FACS analysis was performed using the same protocol as in the in vivo study. This experiment was repeated four times using two to three animals in each group.

\section{Evaluation of antigen-presenting activity of BMDCs}

CSBG-exposed BMDCs were treated with $50 \mu \mathrm{g} / \mathrm{ml}$ mitomycin C (Kyowa Hakko Kogyo, Tokyo, Japan) for 20 min in a water bath at $37^{\circ} \mathrm{C}$. Responder T cells were derived from a pool of splenocytes from OVA-sensitized ICR mice (three mice/each experiment). Briefly, mice were immunized with $40 \mu \mathrm{g}$ OVA and $1 \mathrm{mg} \mathrm{Al}(\mathrm{OH})_{3}$ in $0.1 \mathrm{ml}$ of saline given intraperitoneally, and splenocytes were harvested on day 14 . T cells were isolated from the splenocytes using a nylon fiber column (Wako Pure Chemical Industries). Thereafter, OVA-sensitized T cells $\left(2 \times 10^{5}\right)$ were co-cultured with BMDCs $\left(5 \times 10^{3}\right)$ in the presence of $20 \mu \mathrm{g}$ of OVA in $200 \mu \mathrm{l}$ of R10 medium in 96-well flatbottom plates. The co-culture of BMDCs and T cells was performed in triplicate at $37^{\circ} \mathrm{C}$ in a $5 \% \mathrm{CO}_{2} / 95 \%$ air atmosphere. After $91 \mathrm{~h}$, cell proliferation and cytokine production from $\mathrm{T}$ cells were measured. The same experiment was repeated three times using three animals per group.

\section{Measurement of cell proliferation}

Cell proliferation was measured with a Cell-ProliferationELISA Kit (Roche Molecular Biochemicals, Mannheim, Germany) according to the manufacturer's instructions. This technique is based on the incorporation of the pyrimidine analogue 5-bromo-2'-deoxyuridine (BrdU) instead of thymidine into the DNA of proliferating cells. BrdU incorporated into DNA is measured by a sandwich- 
type enzyme immunoassay using monoclonal anti-BrdU antibodies. Cell proliferation was measured by adding BrdU to each well $20 \mathrm{~h}$ before measurement. Absorbance of the samples was measured in an ELISA plate reader at a wavelength of $450 \mathrm{~nm}$.

\section{Statistical analysis}

Data are reported as the mean \pm SE using Statview version 4.0 (Abacus Concepts, Inc., Berkeley, CA). To examine each (CSBG and OVA) factor's effect and interaction in the combination, two-way ANOVA was performed for in vivo results. Regarding in vitro studies, one-way ANOVA was applied. Bonferroni corrections were used for post hoc tests to examine the difference between the two groups. Significance was assigned to P-values smaller than 0.05.

\section{Results \\ Effects of pulmonary exposure to CSBG on lung inflammation in the presence or absence of OVA}

We investigated the cellular profile of BAL fluid and exhibited representative data ( $25 \mu \mathrm{g}$ of CSBG used: Fig. 1). The number of total cells was significantly greater in the CSBG or CSBG + OVA group than in the vehicle group $(\mathrm{P}<$ $0.01)$. The number was significantly greater in the CSBG + OVA group than in the OVA group $(\mathrm{P}<0.01)$. Exposure to CSBG + OVA increased the number of eosinophils as compared with vehicle exposure $(\mathrm{P}<0.01)$. The number was significantly greater in the CSBG + OVA group than in the CSBG or OVA group $(\mathrm{P}<0.01)$, and synergistic interac-

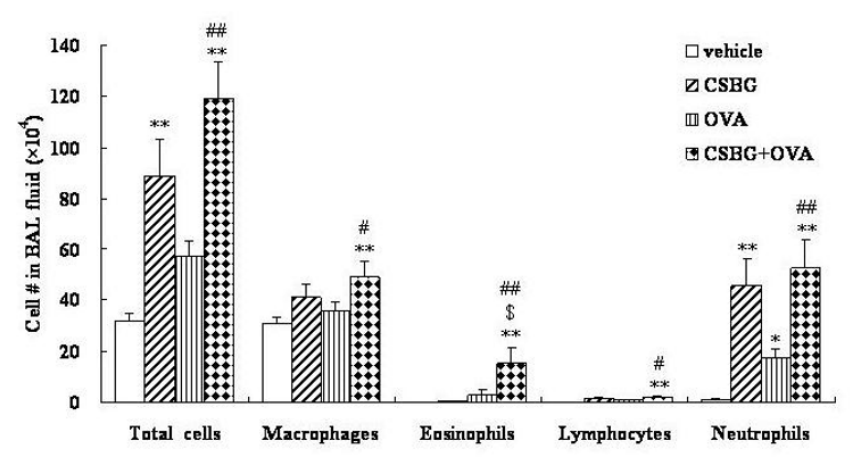

Figure I

Cellularity in bronchoalveolar lavage (BAL) fluid after intratracheal challenge. Four groups of ICR mice were intratracheally administered vehicle, soluble $\beta$-glucan from Candida albicans (CSBG), ovalbumin (OVA), or CSBG + OVA for 4 wk. Bronchoalveolar lavage (BAL) was conducted $24 \mathrm{~h}$ after the last intratracheal instillation. Total cell counts were determined on fresh BAL fluid, and differential cell counts were assessed with Diff-Quik-staining. The results are presented as the mean $\pm \mathrm{SE}$ ( $\mathrm{n}=8$ in each group). $* \mathrm{P}<0.05$ and $* * P<0.01$ vs. vehicle; $\# P<0.05$ and $\# P<0.01$ vs. OVA; $\$ P<0.0$ l vs. CSBG. tion between the two stimulators was noted $(P=0.02)$. The number of lymphocytes was significantly greater in the CSBG + OVA group than in the vehicle group $(\mathrm{P}<$ $0.01)$. The number was greater in the CSBG + OVA group than in the OVA group $(\mathrm{P}<0.05)$. The number of neutrophils was significantly greater in the CSBG $(\mathrm{P}<0.01)$, OVA $(\mathrm{P}<0.05)$, or CSBG + OVA $(\mathrm{P}<0.01)$ group than in the vehicle group. The number was significantly higher in the CSBG + OVA group than in the OVA group $(\mathrm{P}<0.01)$. The number of macrophages was greater in the CSBG + OVA group than in the vehicle group $(\mathrm{P}<0.01)$. The number was further significantly greater in the CSBG + OVA group than in the OVA group $(\mathrm{P}<0.05)$. On the other hand, in experiments using $12.5 \mu \mathrm{g}$ of CSBG, the data are similar as that using $25 \mu \mathrm{g}$, although the significance did not show profoundly (data not shown).

\section{Effects of CSBG on histological changes in the lung in the presence or absence of OVA}

We evaluated lung specimens stained with H\&E $24 \mathrm{~h}$ after the final intratracheal instillation (Fig. 2). No pathological change was noted in lungs obtained from the vehicle group. The infiltration of neutrophils was moderate in the lungs from the CSBG and modest in those from the OVA group. On the other hand, the infiltration of eosinophils was moderate in lungs from the OVA group. Combined treatment with CSBG + OVA appeared to worsen PMN and MON sequestration into the lung parenchyma, as compared with OVA treatment alone.

To quantify the infiltration of inflammatory leukocytes around the airways, we expressed the number of these cells per length of basement membrane of the airways. The number of PMNs was greater in the CSBG $(\mathrm{P}<0.05)$, OVA $(\mathrm{P}<0.05)$, or CSBG + OVA $(\mathrm{P}<0.01)$ group than in the vehicle group. The number was also significantly greater in the CSBG + OVA group than in the CSBG group $(P<0.05)$. The number of MONs was larger in the CSBG + OVA group than in the vehicle group $(\mathrm{P}<0.05)$.

\section{CSBG exacerbates OVA-induced mucus metaplasia}

To evaluate airway epithelial injury and mucus hypersecretion, lung sections were stained with PAS (Fig. 3). CSBG or OVA alone induced modest mucus cell hyperplasia in the airway compared with the vehicle. However, the phenomenon markedly progressed in the CSBG + OVA group compared to the other groups. Semi-quantitative analyses also showed that CSBG or OVA alone modestly increased the number of mucus cells as compared with the vehicle. On the other hand, the number was significantly greater in the CSBG + OVA group than in the vehicle, CSBG, or OVA group $(\mathrm{P}<0.01)$, and synergistic interaction between the two stimulators was noted $(P=0.02)$. 

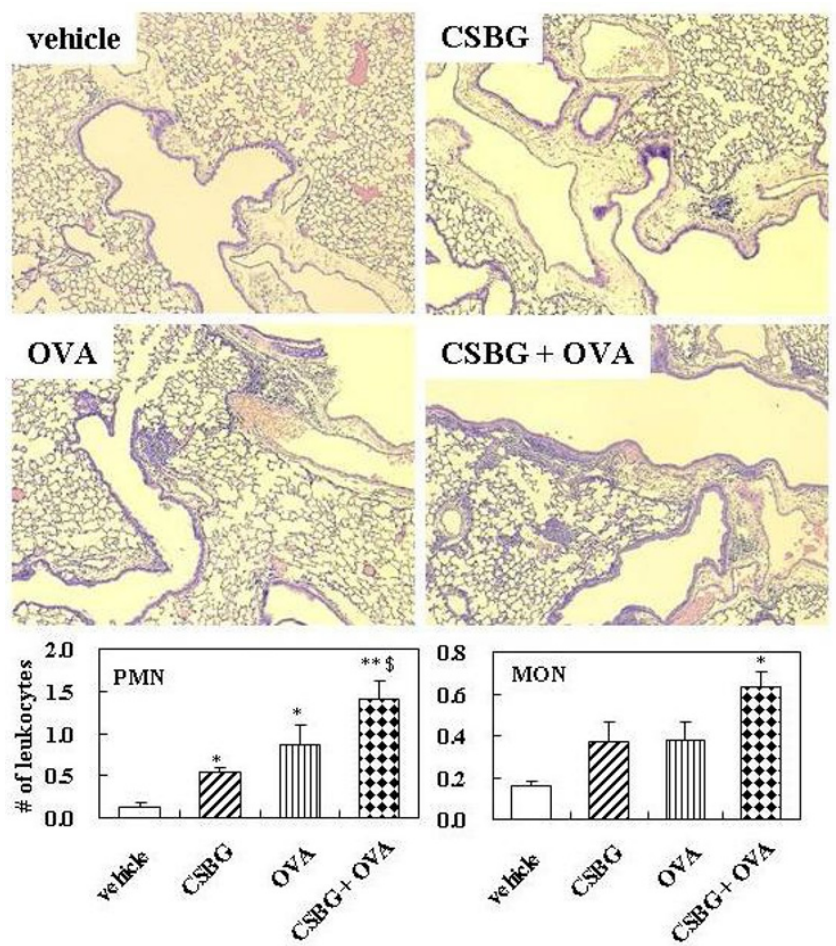

Figure 2

Histological findings of hematoxylin and eosin (H\&E)stained lungs. The 4 groups of mice were intratracheally inoculated with vehicle, CSBG, OVA, or CSBG + OVA for 4 wk. Lungs were obtained $24 \mathrm{~h}$ after the final intratracheal administration, and representative photographs of H\&Estained lung tissues are shown. Original magnification $\times 100$. Polymorphonuclear leukocyte (PMN) and mononuclear cell (MON) infiltration is expressed as the average number of PMNs and MONs per millimeter of basement membrane. Values represent the mean $\pm \mathrm{SE}$ ( $\mathrm{n}=5$ in each group). $* \mathrm{P}<$ 0.01 vs. vehicle; $\$ P<0.05$ vs. CSBG.

Effects of CSBG on the lung expression of cytokines and chemokines in the presence or absence of OVA

We quantified protein levels of cytokines such as IL-4, IL5, IL-13, IFN- $\gamma$, IL-17A, and GM-CSF, and chemokines such as eotaxin, MIP- $1 \alpha$, and KC related to allergic inflammation in the lung tissue homogenates (Fig. 4). Pulmonary exposure to CSBG elevated the levels of MIP-1 $\alpha$ and $\mathrm{KC}$ compared to vehicle exposure $(\mathrm{P}<0.05)$. OVA elevated the levels of IL-5 and IL-13 as compared to vehicle exposure $(\mathrm{P}<0.05)$. On the other hand, CSBG plus OVA markedly increased the levels of all cytokines and chemokines compared to the vehicle $(\mathrm{P}<0.05$ for IL-4, IL-17A, and GM-SCF; P $<0.01$ for IL-5, IL-13, eotaxin, MIP-1 $\alpha$, and KC), CSBG ( $\mathrm{P}<0.05$ for IL-4; $\mathrm{P}<0.01$ for IL-5, IL-13, eotaxin, MIP-1 $\alpha$, and KC), or OVA (P $<0.05$ for IL-4, IL13, IL-17A, and GM-CSF; P < 0.01 for IL-5, eotaxin, MIP$1 \alpha$, and KC). Furthermore, two-way ANOVA revealed syn-
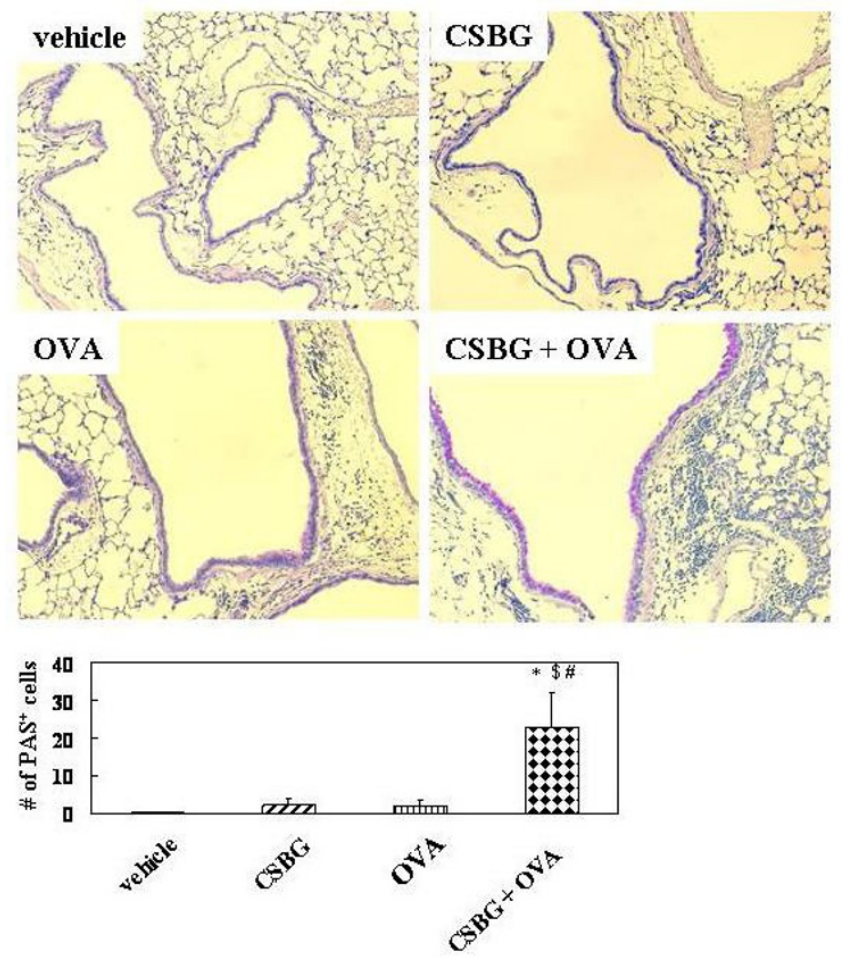

Figure 3

Histological findings of the periodic acid Schiff (PAS)stained lungs. The 4 groups of mice were intratracheally inoculated with vehicle, CSBG, OVA, or CSBG + OVA for 4 wk. Lungs were obtained $24 \mathrm{~h}$ after the final intratracheal administration and representative photographs of PASstained lung tissues are shown. Original magnification $\times 200$. Mucus cell hyperplasia in the bronchial epithelium is expressed as the average number of PAS-positive cells per millimeter of basement membrane. Values represent the mean $\pm S E(n=5$ in each group). $* P<0.0$ I vs. vehicle; $\# P<$ 0.01 vs. OVA; $\$ P<0.01$ vs. CSBG.

ergistic interactions between CSBG and OVA on IL-4, IL-5, IL-13, IL-17A, eotaxin, MIP-1 $\alpha$, and KC $(\mathrm{P}<0.05)$. IFN- $\gamma$ level was not different between the experimental groups (data not shown).

\section{Effects of CSBG on the production of Igs in the presence or absence of OVA}

We measured total IgE and OVA-specific $\operatorname{IgG} \mathrm{G}_{1}, \operatorname{IgE}$, and $I_{2 \mathrm{G}}$ levels (Fig. 5). The total IgE level was greater in the CSBG + OVA group than in the other groups (N. S.). The OVA-specific $\operatorname{IgG}_{1}$ titer was higher in the OVA $(\mathrm{P}<0.05)$ or $\mathrm{CSBG}+$ OVA $(\mathrm{P}<0.01)$ group than in the vehicle group. The titer was further greater in the CSBG + OVA group than in the CSBG group $(\mathrm{P}<0.05)$. OVA-specific IgE concentration was greater in the CSBG + OVA group than in the vehicle group $(\mathrm{P}<0.05)$. The value was also greater in the CSBG + OVA group than in the CSBG group 

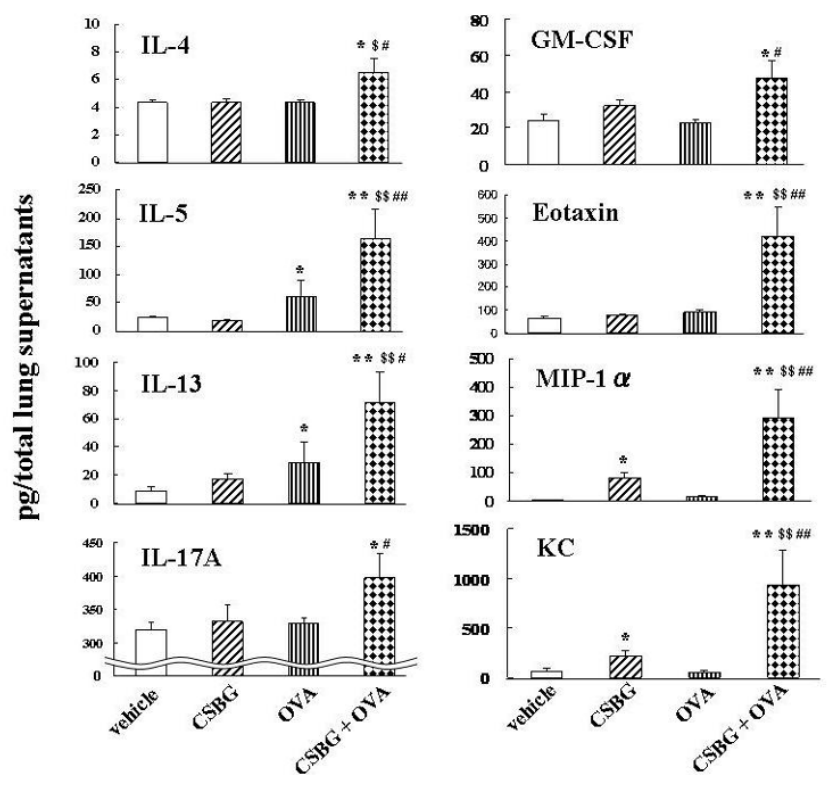

Figure 4

Protein levels of cytokines and chemokines in the lung homogenates. The 4 groups of mice were intratracheally inoculated with vehicle, CSBG, OVA, or CSBG + OVA for 4 wk. Lungs were removed and frozen $24 \mathrm{~h}$ after the last intratracheal administration. Protein levels of interleukin (IL)-4, IL-5, IL- I3, IL- I7A, granulocyte/macrophagecolony-stimulating factor (GM-CSF), eotaxin, macrophage inflammatory protein (MIP)-I $\alpha(\mathrm{C})$, and keratinocyte-derived chemoattractant $(\mathrm{KC})$ in the lung homogenate supernatants were analyzed using ELISA. The results are presented as the mean \pm SE ( $n=8$ in each group). $* P<0.05$ and $* * P<0.01$ vs. vehicle; $\# P<0.05$ and $\# P<0.0$ I vs. OVA; $\$ P<0.05$ and $\$ \$ P<0.01$ vs. CSBG.

$(\mathrm{P}<0.05)$. The OVA-specific $\operatorname{IgG}_{2 \mathrm{a}}$ titer was higher only in the CSBG + OVA group than in other groups $(\mathrm{P}<0.05)$.

\section{Effects of in vivo exposure to CSBG on the expression of MHC class II with or without costimulatory molecules and APC-related markers in lung cells in the presence or absence of OVA}

The number of $\mathrm{MHC}$ class $\mathrm{II}^{+}$cells was greater in the CSBG + OVA group than in the other groups $(P<0.05)$ (Fig. 6). Also, a two-way ANOVA revealed an interaction between CSBG and OVA on the number $(P=0.04)$. The number of $\mathrm{CD}^{2} 0^{+}$or $\mathrm{CD} 86^{+}$cells was greater in the CSBG + OVA group than in the vehicle group $\left(\mathrm{P}<0.05\right.$ for $\mathrm{CD} 80^{+}, \mathrm{P}<$ 0.01 for $\left.\mathrm{CD}^{2} 6^{+}\right)$. Furthermore, the number of MHC class $\mathrm{II}^{+} \mathrm{CD} 80^{+}$or $\mathrm{MHC}$ class $\mathrm{II}^{+} \mathrm{CD} 86^{+}$cells was also greater in the CSBG + OVA group than in the vehicle group $(\mathrm{P}<0.05$ for $\mathrm{MHC}$ class $\mathrm{II}^{+} \mathrm{CD} 6^{+}, \mathrm{P}<0.01$ for $\mathrm{MHC}$ class $\mathrm{II}^{+}$ $\mathrm{CD}^{+} 0^{+}$. The number of $\mathrm{MHC}$ class $\mathrm{II}^{+} \mathrm{CD} 80^{+}$was further greater in the CSBG + OVA group than in the OVA group $(\mathrm{P}<0.05)$. In addition, a two-way ANOVA revealed an
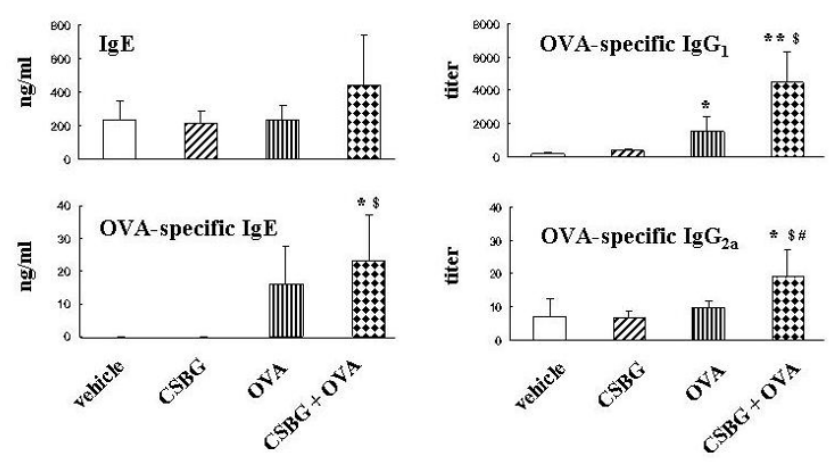

Figure 5

Values of total IgE and OVA-specific $\lg G_{1}, \operatorname{lgG}_{2 a}$, and IgE. The 4 groups of mice were intratracheally administered vehicle, CSBG, OVA, or a combination of CSBG + OVA for 4 wk. Serum samples were retrieved $24 \mathrm{~h}$ after the last intratracheal instillation. Total IgE and OVA-specific $\lg _{1}$, $\operatorname{lgG}_{2 \mathrm{a}}$, and $\mathrm{IgE}$ were analyzed using ELISA. The results are expressed as the mean $\pm S E(n=13$ in each group). $* P<$ 0.05 and $* * P<0.0$ I vs. vehicle; $\# P<0.0$ I vs. OVA; $\$ P<0.0$ I vs. CSBG.

interaction between CSBG and OVA on the number of $\mathrm{MHC}$ class $\mathrm{II}^{+} \mathrm{CD} 80^{+}(\mathrm{P}=0.045)$. The number of $\mathrm{MHC}$ class $\mathrm{II}^{+} \mathrm{CD} 11 \mathrm{C}^{+}$cells was higher in the CSBG $(\mathrm{P}<0.05)$ or the CSBG + OVA $(\mathrm{P}<0.01)$ group than in the vehicle group.

The number of MHC class II+ DEC205+ cells was greater in the CSBG + OVA group than in the vehicle group $(\mathrm{P}<$ $0.05)$. On the other hand, the number of F4/80+ or CD $19^{+}$ cells with or without $\mathrm{MHC}$ class $\mathrm{II}^{+}$was not significantly different among the experimental groups.

\section{Effects of CSBG on splenocyte proliferation in vitro}

The proliferation of splenocytes was examined after exposure to CSBG or DMSO (control) in the presence or absence of OVA for $72 \mathrm{~h}$ (Fig. 7). Exposure to CSBG increased splenocyte proliferation in the absence of OVA in a dose-dependent manner showing an overall trend, with significance at a dose of $12.5 \mu \mathrm{g} / \mathrm{ml}(\mathrm{P}<0.05$ : Fig. 7A). Also, CSBG increased it in the presence of OVA in a dose-independent manner (maximal activity at $1.56 \mu \mathrm{g} /$ $\mathrm{ml}: \mathrm{P}<0.05$ : Fig. 7B).

\section{Action of CSBG on the expression of surface molecules on $B M D C s$ in vitro}

Immature BMDCs were exposed to CSBG for $24 \mathrm{~h}$. The surface expression of MHC class II, CD80, CD86, CD11c, and DEC205 (Fig. 8) on cells was analyzed to estimate the maturation/activation of BMDCs. The percentage of

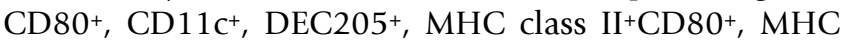
class $\mathrm{II}^{+} \mathrm{CD} 11 \mathrm{c}^{+}$, or $\mathrm{MHC}$ class $\mathrm{II}^{+} \mathrm{DEC} 205^{+}$cells was 

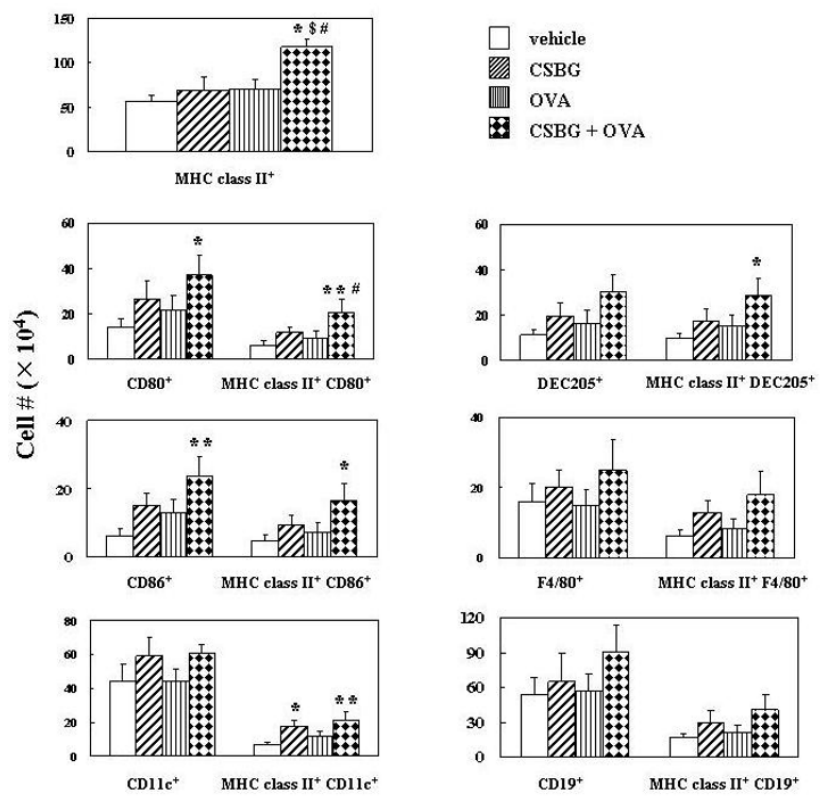

Figure 6

The number of cells expressing MHC class II, costimulatory molecules, and leukocyte markers in the lung. The 4 groups of mice were intratracheally administered vehicle, CSBG, OVA, or a combination of CSBG + OVA for $4 \mathrm{wk}$. Lung cells were prepared $4 \mathrm{~h}$ after the last intratracheal instillation. The expression of cell surface molecules was analyzed by flow cytometry. The numbers of each cell type in the lung are shown. Values are presented as the mean $\pm S E$ ( $n=8$ in each group). $* P<0.05$ and $* * P<0.01$ vs. vehicle; $\# P<0.05$ vs. OVA; $\$ P<0.05$ vs. CSBG.

increased by the addition of CSBG in a dose-dependent fashion with overall trend. Of note, the increase was profoundly in the ratio of double highly positive cells (MHC class II high CD80high, MHC class II ${ }^{\text {high }}$ CD 86 $6^{\text {high }}$, and MHC class II $^{\text {high }}$ DEC205 $\left.{ }^{\text {high }}\right)$ with significance at its high dose $(12.5 \mu \mathrm{g} / \mathrm{ml})(\mathrm{P}<0.05)$ as compared to control.

\section{Effect of CSBG on the OVA-specific syngeneic T-cell- stimulating capacity of BMDCs in vitro}

BMDC function was assessed via their capacity to stimulate antigen-specific syngeneic T-cell proliferation (Fig. 9). The proliferation of T cells (responder cells) was increased by the addition of BMDCs (stimulator cells). The reaction was significantly increased when BMDCs were exposed to more than $1.25 \mu \mathrm{g} / \mathrm{ml}$ of CSBG. Furthermore, Th cytokine (IL-4 and IFN- $\gamma$ ) levels in culture supernatants were measured by ELISA. Although the protein levels were increased by CSBG exposure dose-independently, the difference did not reach statistical significance (data not shown).

\section{Discussion}

The present study has demonstrated that repetitive pulmonary exposure to CSBG potentiates OVA-related eosi-

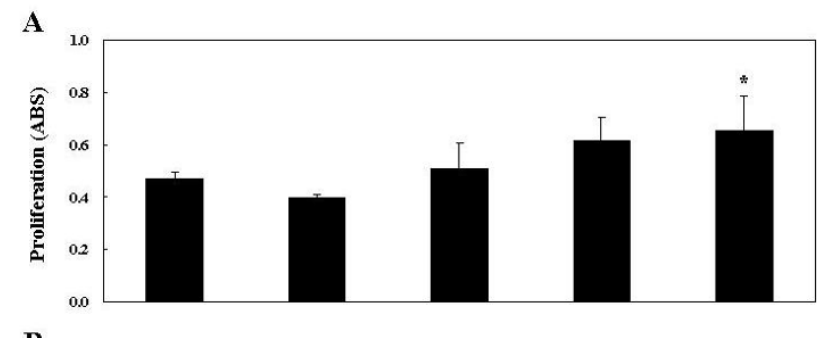

$$
\text { в. }
$$

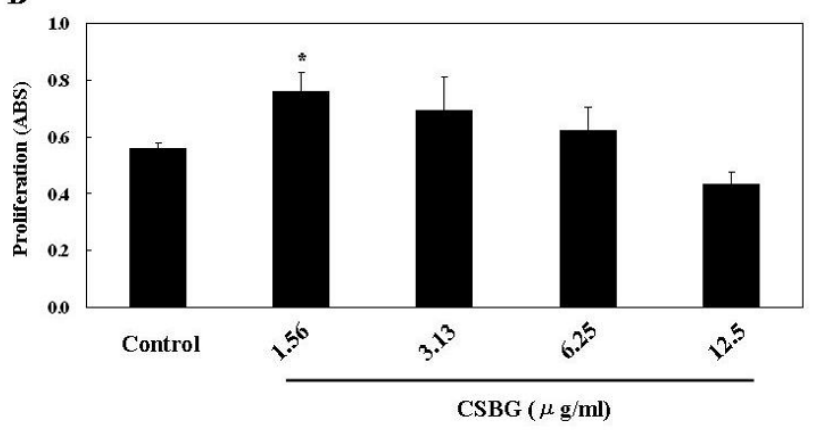

Figure 7

Splenocyte proliferation. Splenocytes $\left(I \times 10^{6} / \mathrm{ml}\right)$ from naïve ICR mice were exposed to CSBG $(1.56-12.5 \mu \mathrm{g} / \mathrm{ml})$ or $0.1 \%$ dimethyl sulfoxide (control) in the absence $(A)$ or presence (B) of OVA $(100 \mu \mathrm{g} / \mathrm{ml})$ in $200 \mu \mathrm{l}$ of R 10 medium for 72 h. Cell proliferation of splenocytes was evaluated by ELISA. Data represent the mean \pm SE of three animals from one experiment representative of three experiments. $* P<0.05$ vs. control.

nophilic airway inflammation with mucus metaplasia, which is concomitant with the increased local expression of proinflammatory cytokines including IL-4, IL-5, IL-13, IL-17A, eotaxin, MIP-1 $\alpha$, and KC. Also, exposure to CSBG plus allergen increases the numbers of MHC class $\mathrm{II}^{+}$cells and those expressing MHC class II and CD80 (a co-stimulatory molecule) in the lung as compared to that of others in vivo. Finally, CSBG increases splenocyte proliferation and partially promotes the phenotypic and functional activation of BMDCs in vitro.

Correlation between fungi and allergic responses has been implicated. Airborne fungi and their products may contribute to the development and exacerbation of allergic airway diseases $[26,27]$. Increased spore counts and fungal allergen levels correlate with allergic symptoms [2830]. Consistent with these epidemiological reports, fungal products including proteins reportedly induce immunologic and proinflammatory reactions and consequent Th2-related responses and the destruction of mucosal barrier functions [31-33]. $\beta$-glucan from both outdoor (Cladosporium herbarum) and indoor (Penicillium chrysogenum) fungi and from baker's yeast exhibit adjuvant properties for Th2 response related to OVA in vivo [8]. Further, peripheral blood mononuclear cells (PBMCs) from 

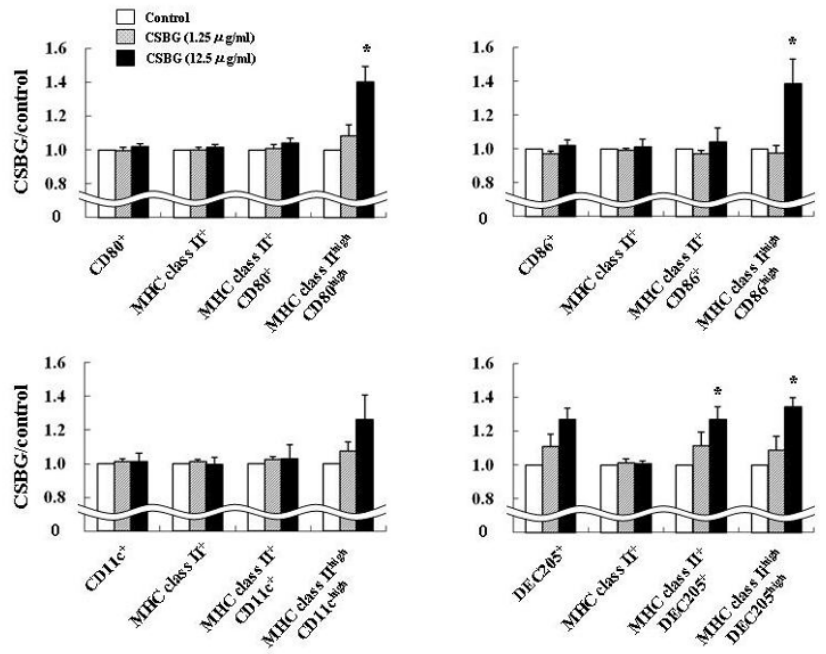

Figure 8

Surface expression of molecules related to antigenpresentation on bone marrow-derived dendritic cells (BMDCs). Immature BMDCs from ICR mice were exposed to CSBG as described in Materials and Methods. After exposure, the expression of molecules related to antigen-presentation was analyzed by flow cytometry. The percentages of each cell type in the BMDC population are shown. Data represent the mean \pm SE of three animals from one experiment, representative of three experiments. $* \mathrm{P}<0.05$ vs. corresponding control.

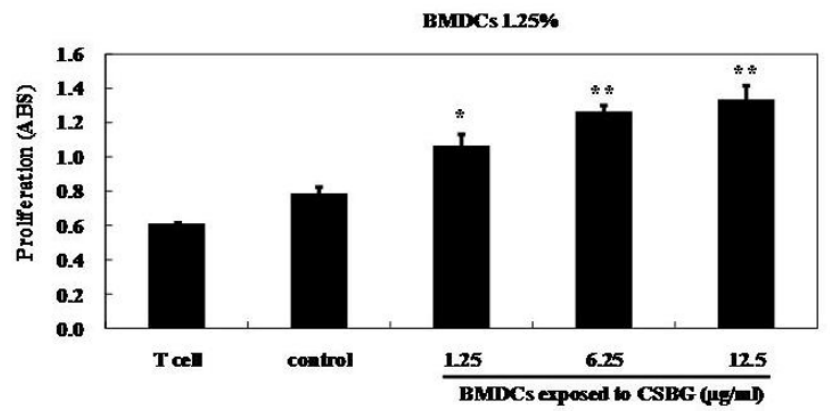

Figure 9

OVA-specific syngeneic T-cell-stimulating capacity of BMDCs. Immature BMDCs from ICR mice were exposed to CSBG in the same manner as shown in Figure 8. Splenic $T$ cells $\left(2 \times 10^{5}\right)$ from OVA-sensitized ICR mice were co-cultured with BMDCs $\left(5 \times 10^{3}\right.$ for I.25\%) from mice in the presence of OVA $(20 \mu \mathrm{g})$ in $200 \mu \mathrm{l}$ of RIO medium for $4 \mathrm{~d}$. Thereafter, T-cell proliferation was evaluated. Data represent the mean \pm SE of three animals from one experiment, representative of three experiments. $* \mathrm{P}<0.05$ and $* * \mathrm{P}<$ 0.01 vs. control. asthma patients produced significantly higher IL-5 protein levels on stimulation with C. albicans than those from non-allergic patients in vitro [34], implicating a role in the exacerbation of asthma. However, scientific evidence regarding the correlation between pathogenic fungi including C. albicans and allergic inflammation is not enough.

Furthermore, investigation of the immunoregulatory effects of cell wall components from fungi has been inadequate. Zymosan, a cell wall preparation mixed with $\beta$ glucan and mannan residues from the fungus Saccharomyces cerevisiae, is known to induce the production of proinflammatory cytokines and chemokines [35,36], and to activate the complement system via an alternative pathway $[37,38]$. Furthermore, zymosan can induce multiple types of immunopathological diseases, resembling human diseases, e.g., peritonitis [39] and arthritis [40], in vivo. It has been indicated, on the other hand, that $\beta$-glucan itself serves various biological activities such as triggering the activation of complement and the production of inflammatory mediators including leukotrienes and tumor necrosis factor- $\alpha[9,10,41]$. However, it has not been fully addressed how $\beta$-glucan derived from clinically important pathogenic fungi modulates the immune response, particularly in vivo. Given the background, CSBG, isolated and solublized from C. albicans, may provide a hint for the impacts of nosocomial fungal infection on the induction/aggravation of allergic airway inflammation, particularly in the context of its responsible constituents.

In the present study, initially, we showed that repetitive intratracheal exposure to CSBG did not induce allergic airway response in terms of lung eosinophilia, the Th2 response, or mucous hyperplasia, suggesting that the component alone does not have potent Th2-related immunogenicity. Possible explanations for this unexpected phenomenon may include the in vivo experimental protocol such as exposure means, dose, and/or duration, and absence of adjuvant. In support of this, exposure to CSBG alone induced a moderate activation of BMDCs and lymphocytes directly (through immunological synapse)/indirectly in vitro. Moreover, we have previously found that a single intratracheal administration of CSBG can induce mucus hyperplasia, one of the consequences of the Th2 (IL-13)-dominant response and the enhanced phosphorylation of STAT6, one of the pivotal transcriptional factors in the Th2 milieu [42]. Thus, other protocols should be examined in future in order to clarify the effects of subacute/chronic exposure to CSBG on the induction of Th2 immunity with pathophysiology. On the other hand, CSBG alone induced airway neutrophilia, whose mecha- 
nisms remain unidentified. We and others have shown that Candida or CSBG can activate innate immunity to produce KC (IL-8), a potent neutrophilic chemoattractant $[13,15,43]$. Furthermore, CSBG has been shown to activate complement systems, including anaphylatoxin (C3a, C5a) release [44]. Accordingly, these mechanisms could be candidates. Alternate, the effects might be caused by other unknown factors co-extracted from C. Albicans other than endotoxin.

In turn, we showed that CSBG synergistically enhanced allergic airway inflammation induced by OVA. The CSBG plus OVA group exhibited significant augmentation of eosinophilic lung inflammation with concomitant amplification of the lung expression of Th2 cytokines and chemokines and related Ig productions in the circulation compared to the OVA group. In addition, phosphorylation of STAT6 in the lung was more potently found in the CSBG + OVA than in the other groups (evidenced by Western blot analysis: data not shown). Thus, it is likely that Candida-derived $\beta$-glucan can synergistically drive a Th2-skewed pathophysiology related to another allergen as a promoter, even if the dose is low enough to barely induce eosinophilic inflammation in the absence of other immunogenic allergen. However, why and how the macromolecule glucose polymers displayed adjuvant effects on the allergic condition when co-administered with relatively low molecular weight OVA must be resolved in the future.

The cellular target of CSBG in the exacerbation on allergic airway inflammation induced by OVA is currently unknown. Our first in vitro experiment implied that CSBG can induce immune cell (splenocyte) activation in the presence or absence of OVA. However, its detailed cellular contribution is not known, since splenocytes contain many immune cell populations such as macrophages/ monocytes, dendritic cells, and lymphocytes. Antigen-presenting cells (APCs) are known to be important for both innate and adaptive immunity. APCs including DCs, macrophages, and B cells play essential roles in the pathogenesis of asthma [45-47]. In particular, DCs are recognized as professional APCs, exhibiting a potent antigen-presenting capacity for T cells [48]. $\beta$-glucan of Candida reportedly promotes the maturation of human monocytegenerated DCs [49]. Therefore, we evaluated the effects of CSBG on the phenotype and function of DCs in vitro. As a result, although CSBG did not significantly enhance the total expression of surface markers (DEC205, CD80, and CD86) as an activation marker and accessory molecules on BMDCs, the rate of highly expressed molecules was significantly greater in the higher concentration of CSBG than the control. On the other hand, CSBG exposure significantly amplified OVA-specific syngeneic T cell reactivity against BMDC. Further, the numbers of cells expressing
MHC class II or MHC class II and CD80 in the lung were significantly greater in the CSBG + OVA group than in the other groups in vivo. Accordingly, the in vitro and in vivo data may lead to the scenario that CSBG can synergistically increase the number of APCs recruited into the lung in asthmatic mice, and, in turn, can amplify the functional activation of APCs including DCs, which confer synergism for the enhancement of asthma pathophysiology. This notion is also supported by the observation that the lung expression of GM-CSF was greater in the CSBG + OVA group than in the other groups, since GM-CSF is a critical cytokine for DC maturation/activation as applied in the present in vitro study.

Whether CSBG preferentially enhances the Th2 response remains obscure. In the present study, CSBG plus OVA amplified the production of OVA-specific $\operatorname{IgG}_{2 \mathrm{a}}$ as compared to OVA alone in vivo and CSBG activated DC to produce/release higher levels of OVA-stimulated IFN- $\gamma$ from T cells than control, implicating its adjuvant activity for Th1 immunity as well as Th2 immunity in vivo and partially in vitro. Furthermore, the lung level of IL-17A was significantly greater in the CSBG + OVA group than in the CSBG or OVA group. The Candida cell wall fraction reportedly exacerbates collagen-induced arthritis, which is concomitant with the elevation of IFN- $\gamma$ and bovine type II collagen-specific $\operatorname{IgG}_{2 \mathrm{a}}$ [50]. On the other hand, C. albicans extract induces IL-5 production from PBMCs in asthmatic patients in vitro [51]. In addition, Th17 cells were recently implicated in host immunity against Candida infection [52] as well as allergic inflammation [53]. Thus, it may be proposed that CSBG can induce both Th1- and Th2-, and even Th17-mediated immunopathology, whose dominance may depend on the study designs (in vivo, in vitro), tissues (lung, joint)/cells (isolated/generated from splenocytes, PBMCs), and/or the driving mode (Th1/Th2/Th17 conditions). Otherwise, from our present results, it is likely that CSBG disrupts Th immunity, especially under pathological Th conditions, in vivo.

\section{Conclusion}

In summary, repetitive pulmonary exposure to CSBG facilitated allergic lung inflammation, at least partly, via the enhanced expression of Th cytokines. As for possible cellular mechanisms, these CSBG's effects were correlated with the phenotypic and functional activation of APCs including DCs, and partly with the migration/infiltration of these cell populations in the inflamed tissues. These results provide evidence for pathogenesis of asthma development and/or exacerbation due to (biological and residence) environmental factors.

\section{Abbreviations}

(CSBG): soluble $\beta$-glucan from C. albicans; (STAT): signal transducer and activator of transcription; (OVA): ovalbu- 
min; (BMDC): bone marrow-derived dendritic cell; (OXCA): NaClO-oxidized candida; (DMSO): dimethyl sulfoxide; (PBS): phosphate-buffered saline; (BAL): bronchoalveolar lavage; (H\&E): hematoxylin and eosin; (PAS): periodic acid-Schiff; (PMN): polymorphonuclear leukocyte; (MON): mononuclear cell; (IL): interleukin; (IFN): interferon; (GM-CSF): granulocyte/macrophage-colonystimulating factor; (MIP): macrophage inflammatory protein; (KC): keratinocyte-derived chemoattractant; (BSA): bovine serum albumin; (BrdU): 5-bromo-2'-deoxyuridine; (N. S.): not significant; (PBMC): peripheral blood mononuclear cell; (APC): antigen-presenting cell.

\section{Competing interests}

The authors declare that they have no conflicting interests.

\section{Authors' contributions}

KI performed all procedures of in vivo experiments and wrote the first draft of the manuscript. EK performed all procedures of in vitro experiments. RY participated in sample and data collection. TO and HTam contributed to the study design and synthesis of CSBG. YA, KI, and NO contributed to all aspects of study design. HTak assisted in data analysis and editing the manuscript. All authors have read and approved the final version of the manuscript.

\section{Acknowledgements}

This study was partly supported by grants from Seikagaku Biobusiness Corporation.

\section{References}

I. Frew AJ: Advances in environmental and occupational disorders. J Allergy Clin Immunol 2003, I I I (3 Suppl):S824-828.

2. Platts-Mills T, Vaughan J, Squillace S, Woodfolk J, Sporik R: Sensitisation, asthma, and a modified Th2 response in children exposed to cat allergen: a population-based cross-sectional study. Lancet 200I, 357:752-756.

3. Becker A, Chan-Yeung M: Primary asthma prevention: is it possible? Curr Allergy Asthma Rep 2008, 8:255-26l.

4. Becker R: Fungal disfigurement of constructions - analysis of the effects of various factors. In Health implications of fungi in indoor environments. Air Quality Monographs Edited by: Samson RA, Flannigan B. Amsterdam: Elsevier; 1994:361-380.

5. Gravesen S, Frisvad JC, Samson RA: Microfungi. Copenhagen: Munksgaard; 1994:6-165.

6. Garrett MH, Rayment PR, Hooper MA, Abramson MJ, Hooper BM: Indoor airborne fungal spores, house dampness and associations with environmental factors and respiratory health in children. Clin Exp Allergy 1998, 28:459-467.

7. O'Connor GT, Walter M, Mitchell H, Kattan M, Morgan WJ, GruchaIla RS, Pongracic JA, Smartt E, Stout JW, Evans R, Crain EF, Burge HA: Airborne fungi in the homes of children with asthma in lowincome urban communities: The Inner-City Asthma Study. J Allergy Clin Immunol 2004, I I 4:599-606.

8. Instanes C, Ormstad H, Rydjord B, Wiker HG, Hetland G: Mould extracts increase the allergic response to ovalbumin in mice. Clin Exp Allergy 2004, 34: 1634-164I.

9. Czop JK, Austen KF: Generation of leukotrienes by human monocytes upon stimulation of their beta-glucan receptor during phagocytosis. Proc Natl Acad Sci USA 1985, 82:275I-2755.

10. Hoffman OA, Standing JE, Limper AH: Pneumocystis carinii stimulates tumor necrosis factor-alpha release from alveolar macrophages through a beta-glucan-mediated mechanism. J Immunol 1993, 150:3932-3940.
II. Ishibashi K, Miura NN, Adachi Y, Tamura H, Tanaka S, Ohno N: The solubilization and biological activities of Aspergillus beta-(I-> 3)-D-glucan. FEMS Immunol Med Microbiol 2004, 42: I55-I66.

12. Ohno N, Uchiyama M, Tsuzuki A, Tokunaka K, Miura NN, Adachi Y, Aizawa MW, Tamura H, Tanaka S, Yadomae T: Solubilization of yeast cell-wall beta-(I-->3)-D-glucan by sodium hypochlorite oxidation and dimethyl sulfoxide extraction. Carbohydr Res 1999, 316:161-172.

13. Ishibashi K, Miura NN, Adachi Y, Ogura N, Tamura H, Tanaka S, Ohno N: Relationship between the physical properties of Candida albicans cell well beta-glucan and activation of leukocytes in vitro. Int Immunopharmacol 2002, 2: I I09-I I 22.

14. Tokunaka K, Ohno N, Adachi Y, Miura NN, Yadomae T: Application of Candida solubilized cell wall beta-glucan in antitumor immunotherapy against P8I5 mastocytoma in mice. Int Immunopharmacol 2002, 2:59-67.

15. Inoue K, Takano H, Oda T, Yanagisawa R, Tamura H, Ohno N, Adachi Y, Ishibashi K, Yoshikawa T: Candida soluble cell wall beta-Dglucan induces lung inflammation in mice. Int J Immunopathol Pharmacol 2007, 20:499-508.

16. Noverr MC, Noggle RM, Toews GB, Huffnagle GB: Role of antibiotics and fungal microbiota in driving pulmonary allergic responses. Infect Immun 2004, 72:4996-5003.

17. Noverr MC, Falkowski NR, McDonald RA, McKenzie AN, Huffnagle GB: Development of allergic airway disease in mice following antibiotic therapy and fungal microbiota increase: role of host genetics, antigen, and interleukin-13. Infect Immun 2005, 73:30-38.

18. Crook WG: Candida colonization and allergic phenomena. Hosp Pract (Off Ed) 1985, 20:12.

19. Saijo S, Fujikado N, Furuta T, Chung SH, Kotaki H, Seki K, Sudo K, Akira S, Adachi Y, Ohno N, Kinjo T, Nakamura K, Kawakami K, Iwakura Y: Dectin-I is required for host defense against Pneumocystis carinii but not against Candida albicancs. Nat Immunol 2007, 8:39-46.

20. Inoue K, Koike E, Takano H, Yanagisawa R, Ichinose T, Yoshikawa T: Effects of diesel exhaust particles on antigen-presenting cells and antigen-specific Th immunity in mice. Exp Biol Med 2009, 234:200-209.

2I. Takano H, Yoshikawa T, Ichinose T, Miyabara Y, Imaoka K, Sagai M: Diesel exhaust particles enhance antigen-induced airway inflammation and local cytokine expression in mice. $\mathrm{Am}$ Respir Crit Care Med 1997, 156:36-42.

22. Takano H, Yanagisawa R, Ichinose T, Sadakane K, Yoshino S, Yoshikawa T, Morita M: Diesel exhaust particles enhance lung injury related to bacterial endotoxin through expression of proinflammatory cytokines, chemokines, and intercellular adhesion molecule-I. Am J Respir Crit Care Med 2002, 165:1329-1335

23. Koike E, Kobayashi $\mathrm{T}$ : Ozone exposure enhances antigen-presenting activity of interstitial lung cells in rats. Toxicology 2004, 196:217-227.

24. Koike E, Takano H, Inoue K, Yanagisawa R, Kobayashi T: Carbon black nanoparticles promote the maturation and function of mouse bone marrow-derived dendritic cells. Chemosphere 2008, 73:37I-376.

25. Lutz MB, Kukutsch N, Ogilvie AL, Rossner S, Koch F, Romani N, Schuler G: An advanced culture method for generating large quantities of highly pure dendritic cells from mouse bone marrow. J Immunol Methods 1999, 223:77-92.

26. Inoue $Y$, Matsuwaki $Y$, Shin SH, Ponikau JU, Kita H: Nonpathogenic, environmental fungi induce activation and degranulation of human eosinophils. J Immunol 2005, I 75:5439-5447.

27. Bush RK, Prochnau Jj: Alternaria-induced asthma. J Allergy Clin Immunol 2004, I I 3:227-234.

28. Dill I, Niggemann B: Domestic fungal viable propagules and sensitization in children with IgE mediated allergic diseases. Pediatr Allergy Immunol 1996, 7:151-155.

29. Li CS, Hsu LY: Airborne fungus allergen in association with residential characteristics in atopic and control children in a subtropical region. Arch Environ Health 1997, 52:72-79.

30. Aukrust L, Almeland TL, Refsum D, Aas K: Severe hypersensitivity or intolerance reactions to measles vaccine in six children. Clinical and immunological studies. Allergy 1980, 35:58I-587.

31. Kauffman HF, Tomee JF, Werf TS van der, de Monchy JG, Koeter GK: Review of fungus-induced asthmatic reactions. Am J Respir Crit Care Med 1995, 151:2109-2115. 
32. Tomee JF, Kauffman HF: Putative virulence factors of Aspergillus fumigatus. Clin Exp Allergy 2000, 30:476-484.

33. Kheradmand F, Kiss A, Xu J, Lee SH, Kolattukudy PE, Corry DB: A protease-activated pathway underlying Th cell type 2 activation and allergic lung disease. J Immunol 2002, 169:5904-59II.

34. Kimura M, Tsuruta S, Yoshida T: Differences in cytokine production by peripheral blood mononuclear cells (PBMC) between patients with atopic dermatitis and bronchial asthma. Clin Exp Immunol 1999, I 1 8: 192-196.

35. Gantner BN, Simmons RM, Canavera SJ, Akira S, Underhill DM: Collaborative induction of inflammatory responses by dectin- $I$ and Toll-like receptor 2. J Exp Med 2003, 197: I I07-I II7.

36. Brown GD, Herre J, Williams DL, Willment JA, Marshall AS, Gordon S: Dectin-I mediates the biological effects of beta-glucans. J Exp Med 2003, 197: I I 19-1 I 24.

37. Fearon DT, Austen KF: Activation of the alternative complement pathway due to resistance of zymosan-bound. Proc Natl Acad Sci USA 1977, 74:1683-1687.

38. Guo RF, Ward PA: Role of C5a in inflammatory responses. Annu Rev Immunol 2005, 23:82I-852.

39. Kolaczkowska E, Barteczko M, Plytycz B, Arnold B: Role of lymphocytes in the course of murine zymosan-induced peritonitis. Inflamm Res 2008, 57:272-278.

40. Conte Fde P, Barja-Fidalgo C, Verri WA Jr, Cunha FQ, Rae GA, Penido C, Henriques MG: Endothelins modulate inflammatory reaction in zymosan-induced arthritis: participation of LTB4, TNF-alpha, and CXCL-I. J Leukoc Biol 2008, 84:652-660.

41. Kataoka K, Muta T, Yamazaki S, Takeshige K: Activation of macrophages by linear (I right-arrow3)-beta-D-glucans. Impliations for the recognition of fungi by innate immunity. J Biol Chem 2002, 277:36825-3683I

42. Nakamura $Y$, Hoshino $M$ : TH2 cytokines and associated transcription factors as therapeutic targets in asthma. Curr Drug Targets Inflamm Allergy 2005, 4:267-270.

43. Overland G, Stuestol JF, Dahle MK, Myhre AE, Netea MG, Verweij P, Yndestad A, Aukrust P, Kullberg BJ, Warris A, Wang JE, Aasen AO: Cytokine responses to fungal pathogens in Kupffer cells are Toll-like receptor 4 independent and mediated by tyrosine kinases. Scand J Immunol 2005, 62: I48-I54.

44. Tokunaka K, Ohno N, Adachi Y, Tanaka S, Tamura H, Yadomae T: Immunopharmacological and immunotoxicological activities of a water-soluble |-->3)-beta-D-glucan, CSBG from Candida spp. Int Immunopharmacol 2000, 22:383-394.

45. Upham JW: The role of dendritic cells in immune regulation and allergic airway inflammation. Respirology 2003, 8: 140-148.

46. Kato T, Tada-Oikawa S, Takahashi K, Saito K, Wang L, Nishio A, Hakamada-Taguchi R, Kawanishi S, Kuribayashi K: Endocrine disruptors that deplete glutathione levels in APC promote Th2 polarization in mice leading to the exacerbation of airway inflammation. Eur J Immunol 2006, 36: I I 99-1209.

47. Lambrecht $\mathrm{BN}$, Hammad $\mathrm{H}$ : Taking our breath away: dendritic cells in the pathogenesis of asthma. Nat Rev Immunol 2003, 3:994-1003.

48. Rossi M, Young JW: Human dendritic cells: potent antigen-presenting cells at the crossroads of innate and adaptive immunity. J Immunol 2005, I75: I373-I38I.

49. Nisini R, Torosantucci A, Romagnoli G, Chiani P, Donati S, Gagliardi MC, Teloni R, Sargentini V, Mariotti S, lorio E, Cassone A: beta-Glucan of Candida albicans cell wall causes the subversion of human monocyte differentiation into dendritic cells. J Leukoc Biol 2007, 82: ||36-| | 42.

50. Yordanov M, Tchorbanov A, Ivanovska N: Candida albicans cellwall fraction exacerbates collagen-induced arthritis in mice. Scand J Immunol 2005, 6 I:30 I-308.

51. Mori A, lkeda Y, Taniguchi M, Aoyama C, Maeda Y, Hasegawa M, Kobayashi N, Akiyama K: IL-5 production by peripheral blood Th cells of adult asthma patients in response to Candida albicans allergen. Int Arch Allergy Immunol 200I, I 25(Suppl I):48-50.

52. Conti HR, Shen F, Nayyar N, Stocum E, Sun JN, Lindemann MJ, Ho AW, Hai JH, Yu JJ, Jung JW, Filler SG, Masso-Welch P, Edgerton M, Gaffen SL: Th 17 cells and IL- 17 receptor signaling are essential for mucosal host defense against oral candidiasis. J Exp Med 2009, 206:299-3II.

53. Wang YH, Liu YJ: The IL-17cytokine family and their role in allergic inflammation. Curr Opin Immunol 2008, 20:697-702.

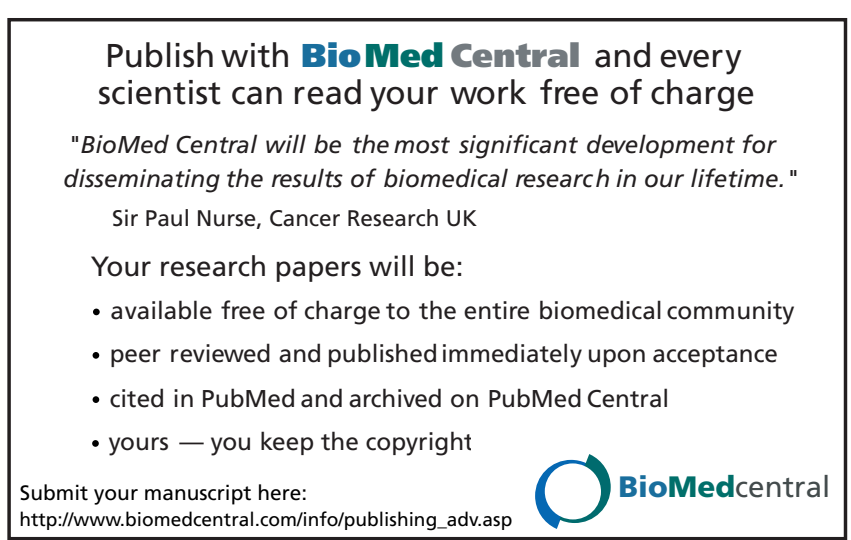

